2019-09-01

\title{
Women offenders: Promoting a holistic approach and continuity of care across criminal justice and health interventions
}

\author{
Annison, CJ::0000-0002-5441-6525
}

http://hdl.handle.net/10026.1/11259

\subsection{7/1748895818773805 \\ Criminology and Criminal Justice \\ SAGE Publications}

All content in PEARL is protected by copyright law. Author manuscripts are made available in accordance with publisher policies. Please cite only the published version using the details provided on the item record or document. In the absence of an open licence (e.g. Creative Commons), permissions for further reuse of content should be sought from the publisher or author. 


\section{Women Offenders: Promoting a Holistic Approach and Continuity of Care across Criminal Justice and Health Interventions}

\section{Jill Annison}

University of Plymouth

\section{Richard Byng}

University of Plymouth

\section{Cath Quinn}

University of Plymouth

\section{Corresponding Author:}

Jill Annison, School of Law, Criminology and Government, 20 Portland Villas, University of Plymouth, Drake Circus, Plymouth. PL4 8AA, UK. Email: jannison@plymouth.ac.uk

\section{Full details:}

Dr Jill Annison,

Associate Professor (Senior Lecturer),

School of Law, Criminology and Government,

20 Portland Villas,

University of Plymouth,

Drake Circus,

Plymouth, Devon.

PL4 8AA

$\begin{array}{ll}\text { Telephone number: } & \text { +44 } 1752585752 \\ \text { Fax number: } & \text { +44 } 1752585508 \\ \text { Email address: } & \text { J.Annison@ @ plymouth.ac.uk }\end{array}$ 
Professor Richard Byng

Professor in Primary Care Research/PenCLAHRC Deputy Director

Clinical Trials \& Health Research - Institute of Translational \& Stratified Medicine Faculty of Medicine and Dentistry

University of Plymouth

N14, ITTC, Drake Circus, Plymouth, Devon, PL4 8AA

+44 1752764260

richard.byng@plymouth.ac.uk

Dr Cath Quinn

Senior Research Fellow

Clinical Trials \& Health Research - Institute of Translational \& Stratified Medicine Faculty of Medicine and Dentistry

University of Plymouth

N6, Tamar Science Park, Drake Circus, Plymouth, Devon, PL4 8AA

+44 1752764274

cath.quinn@plymouth.ac.uk

Final word count:

Abstract: 146

Key words: 6 (total words - 10)

Journal article: 8,055 (including Tables 1 and 2)

Acknowledgements: 55

Declaration of conflicting interests: 21

Funding: 90

Notes: 155

References: 1,675

Short Biography of each author: 48 / 45 / 34 (details of ORCID ID also given for each author) 


\begin{abstract}
Analysis of data in this article focuses on the self-reported situations of 21 female respondents who were part of a large-scale study of offenders' health needs. The findings show an extensive range of physical and psychological problems, often intertwined with substance misuse and other issues, including offending behaviour. Four components of an existing model of 'continuity of care' are reviewed to explore the difficulties, but also the potential, for collaborative and co-ordinated interventions with regard to working with women offenders. Concern is expressed about the changes and fragmentation in provision for women brought about by the Transforming Rehabilitation agenda in England and Wales. It is advocated here that policy and practice should be developed across health and criminal justice agencies to provide holistic and integrated approaches which could support women offenders in their attempts to stabilise their lives and to find pathways out of crime.
\end{abstract}

\title{
Keywords
}

Women offenders; Continuity of care; Transforming Rehabilitation; Probation; Health; Access. 


\section{Introduction}

The operationalisation of the 'Transforming Rehabilitation' (TR) programme in England and Wales in 2015 (Ministry of Justice 2013, Strickland 2016) has created a National Probation Service, which has retained responsibility for the supervision of high risk offenders, while the management of low to medium risk offenders has been outsourced to eight providers across the 21 newly formed Community Rehabilitation Companies (CRCs). With the enactment of the Offender Rehabilitation Act 2014 the CRCs also have responsibility for the supervision of short-term prisoners after release, i.e. those sentenced to less than 12 months in prison (Clinks 2016). These criminal justice system focused reforms do not address the need for cross sectoral working; this paper explores how we might think about the joined-up whole person approaches, which are particularly important for women offenders.

In anticipation of the TR reforms concerns were expressed, particularly in relation to political and ideological imperatives, which rested on the privatisation of services to a range of CRC providers and the inclusion of a payment by results element (Annison, Burke and Senior 2014). This posed concomitant misgivings about the potential fragmentation of provision and the possible lack of cohesion across the criminal justice and associated fields, especially concerning women offenders. For example, attention 
was drawn to the existing range of inter-linked contracts with respect to women service-users across health and crime commissioning streams, as well as community and post-custodial supervision, with these parallel processes impacting on the same individuals (Gomm 2013: 156).

This apprehension about the impact on women offenders was noted in the proceedings of the Justice Select Committee:

The Government's proposals for Transforming Rehabilitation have clearly been designed to deal with male offenders. Funding arrangements for provision for women appear to be being shoehorned into the payment by results programme, resulting in the likelihood of a loss of funding for broader provision encompassing both women offenders and those with particular vulnerabilities that put them at risk of offending.

(House of Commons Justice Committee 2013: 86)

It was subsequently clarified in the 2014 Offender Rehabilitation Act that the legislation expected: 
The Secretary of State to ensure that contracts or other arrangements providing for the supervision or rehabilitation of offenders must (a) state that the Secretary of State has complied with the public sector equality duty in Section 149 of the Equality Act 2010 as it relates to female offenders; and (b) identify anything in the arrangements that is intended to meet the particular needs of female offenders.

(Prison Reform Trust 2013: 6)

There is therefore a legislative requirement for the needs of female offenders to be taken into account as the new organisational arrangements are operationalised. However, in turn this raises inherent issues about the particular needs of female offenders and how they could, and should, be responded to.

This article contributes to this area, first by presenting a contextual review of relevant policy and practice developments relating to women offenders in England and Wales, particularly those serving sentences in the community. It then moves on to outline and analyse the quantitative and qualitative findings relating to women offenders from a research study conducted by the authors of this article (Byng et al. 2012). This focused on the health needs of offenders, particularly in relation to the range of issues 
and problems reported by these respondents. Furthermore, it explored the way that the health and criminal justice systems could best work together to improve health outcomes and to support offenders' endeavours to move towards desistance from crime. This is of particular importance as:

In comparison to the male population, women in the CJS experience higher rates of self-harm and eating disorders; are twice as likely to suffer from depression and anxiety; are more likely to have symptoms associated with post-traumatic stress disorder; and are more likely to have a mental illness.

(Clinks 2015: 1)

Our study found that women offenders are likely to have a poor health status, which has an impact both on their daily lives and on their ability to self-care. The extent of these problems is revealed, showing a complex and overlapping set of health, social and structural problems which we suggest should be understood from a whole-woman perspective: this should take into account the ways in which women who are caught up in the criminal justice system can be supported to improve their lives. The criminological critique developed here, drawing on findings from a health-related research study, thus provides valuable insights from these inter-disciplinary viewpoints. 
This article explores the findings in relation to the 21 female participants in the study within a theoretical framework that draws on the concept of continuity of care (Freeman et al. 2002; Jones et al. 2009). This approach facilitates analysis of the complexity of needs experienced by many women offenders. Moreover, interrogating the richness of this data from the perspective of the women themselves addresses concerns that have been raised and that are relevant to the TR agenda:

Neglecting service users' insights may lead to under-estimating resource needs, unrealistic target setting, and the eventual abandonment of promising ideas in favour of the next 'new' magic bullet.

(Hedderman, Gunby and Shelton, 2011: 3)

Finally, the data, which was collected prior to the recent changes, is reviewed within the context of the unfolding TR scenario and health developments in the justice system in England and Wales. The radical nature of these changes are posing significant challenges; the findings and analysis within this article interrogate these important issues and make recommendations in respect of the adoption of holistic and integrated interventions for women offenders. 


\section{The Wider Context: Corston and Beyond}

Within the criminal justice field in England and Wales the publication of the Corston Report drew attention to the "group of women offenders who have multiple needs" (Corston 2007: Terms of Reference, Appendix B). Although most of the 43 recommendations of the Corston Report were accepted in full or in principle by the Labour Government then in power:

The revolutionary extent of change advocated by Corston was ultimately constrained by the continuing entrenchment of prison as a sentencing sanction for women - a pivot around which policy and practice continued to revolve.

(Annison, Brayford and Deering 2015a: 255-256)

Corston identified personal circumstances, including mental illness, low self-esteem, eating disorders and substance misuse, as one of the three main categories of vulnerability for women ${ }^{1}$. She reported that drug addiction played a large part in all offending and was disproportionately the case with women. Mental health problems were far more prevalent among women in prison than in the male prison population or in the general population. Moreover, mental health services in the community were 
failing to adequately address the mental health needs of such women. Women coming into prison had worse physical, psychological and social health than the group in the general population with the poorest health. In responding to these issues she recommended an integrated approach to addressing women offenders' health and wellbeing (Corston 2007).

Over recent years there have been theoretical critiques and research studies with regard to policy and practice developments in England and Wales for women offenders (Seal and Phoenix 2013), alongside reviews and evaluation of gender-specific provision (Gelsthorpe, Sharpe and Roberts 2007; Hedderman, Palmer and Hollin 2008). In addition, the needs and problems of women offenders in terms of interventions in the community and within custodial institutions have been explored, in respect of the UK and from international perspectives (for example, Sheehan, Mclvor and Trotter 2007; 2011).

Progressive practice initiatives in line with the Corston Report developed provision which included women-only spaces (Asher and Annison 2015), multi-agency collaboration and open-ended support to aid desistance (Mclvor, Trotter and Sheehan 2009). Of particular importance is the observation - and general consensus by 
academics and practitioners - that methods of practice should not "simply continue the "add and stir" approach to female offender intervention" (Chesney-Lind and Pasko 2013: 180).

Turning to research in the health field, continuity of care is reported as being valued by both patients and practitioners in health services research (Donahue, Ashkin and Pathman 2005; Kearley, Freeman and Heath 2001; Nutting et al. 2003; Schers et al. 2002; Tarrant et al. 2003). Primary care research has identified numerous potential factors as being important for positive experiences of continuity, some of which take into account the particular needs of more vulnerable patient groups (Lester, Tritter and Sorohan 2005; Freeman et al. 2002).

The COCOA (Care for Offenders, Continuity of Access) study adopted an adapted version of Freeman et al's revised definition of continuity of care (Freeman et al. 2001), which acknowledged that access to a co-ordinated progression of care depends on the social context being taken into account, and incorporates four subcomponents: longitudinal continuity; relational (personal and therapeutic) continuity; flexible continuity; and effective communication (referred to as continuity of communication). 
In order to explore and critique these issues this article now draws on the quantitative and qualitative findings from the women respondents within the study (Byng et al. 2012). In particular, the data and analysis from this empirical study provides insights into elements of, and barriers and facilitators for, continuity of care for offenders. This links the women's reports of their health problems, with wider issues relating to their experiences of the criminal justice system, their hopes to move towards desistance from crime, and to a position of general well-being and stability in their lives.

\section{The COCOA Study}

The COCOA study (Byng et al. 2012) aimed to examine how, and in what situations, the health and criminal justice systems could best work together and how this could enhance the health, and reduce recidivism, of offenders. In order to investigate these aspects the objectives of the research were to determine:

- The current status of continuity of care for offenders;

- The essential elements of, and facilitators for, continuity of care for offenders; and,

- Potentially effective models of healthcare service delivery for offenders. 
The study adopted a multi-method approach using a 'subtle realist' perspective (Hammersley 2002) and was influenced by realistic evaluation methodology (Pawson and Tilley 1997). During the interviews respondents were taken through a semistructured questionnaire which elicited responses in relation to aspects from five sections:

Section A Details of demographic status, issues of social exclusion and contact with the criminal justice system;

Section B Information regarding perceived health problems, GP registration status, on-going care requirements for different health problems (medication, reviews, etc.)

Section C This was the core of the interview and involved the use of a pictorial diagram, mapping contact with criminal justice agencies and health services over a six month period.

Section D Specific questions relating to elements of continuity, such as the respondents' willingness to agree to information sharing between professionals involved in their case. Other questions related to issues such as trust and stigma.

Section E Questions in this part enquired about avoiding reoffending and healthcare's potential contribution to that. 
The final report (Byng et al. 2012) included a synthesis of qualitative and quantitative data at organisational and offender levels, with the qualitative data being subjected to analyses via an a priori coding frame drawing on the phases of the criminal justice system and known components of continuity, and then by an inductive thematic analysis of the respondents' experiences and perceptions of their experiences (see Byng et al. 2012: 62).

\section{Focus on Women Offenders}

Although the overall report (Byng et al. 2012) contained information about the women respondents it was acknowledged that the study population was dominated by the males in the sample (179 out of a total of 200); there were only 21 female offender participants. While the women respondents could therefore be considered as 'correctional afterthoughts' (Ross and Fabiano 1987) in the main study, they have become the key focus in this article. The next sections thus provide an outline of the study strategy, descriptive quantitative data, and then extend the range and depth of analysis by reviewing the qualitative responses that the women respondents gave in initial and (for some ${ }^{2}$ ) follow-up interviews. 


\section{The research process}

The study drew respondents from two main case study sites: one urban area in the South West of England and one in the South East of England. The inclusion of women in prison was not possible due to practical and governance problems. Consequently, the women respondents were recruited in the community via staff in two Probation Trust areas, with all interviews taking place on probation premises.

This process resulted in the recruitment of a total of 21 female respondents, 12 at the SW site (Respondents 1-12) and 9 from the SE case study area (Respondents 13-21). The set-up and timing of the interviews allowed for respondents to elaborate on their qualitative responses if they so wished. The interviews were conducted via a face-toface meeting with a researcher, with most lasting approximately 45 minutes, and, when possible, were digitally audio recorded and transcribed verbatim.

\section{Personal and social situations of the women respondents}

This section provides an overview of the 21 female respondents' situations, with a summary of the community sentence or licence being served and then outlines demographic and socio-economic factors, supplemented with some quotes from respondents to illuminate the descriptive information. 
Table 1: Ages, sentence type and duration, and previous community and custodial sentences of respondents:

\begin{tabular}{|c|c|c|c|c|c|}
\hline Respondent & Age & $\begin{array}{l}\text { Type of } \\
\text { current } \\
\text { sentence }\end{array}$ & $\begin{array}{l}\text { Length of } \\
\text { current } \\
\text { sentence }\end{array}$ & $\begin{array}{l}\text { Number of } \\
\text { previous } \\
\text { community } \\
\text { sentences }\end{array}$ & $\begin{array}{l}\text { Number of } \\
\text { previous } \\
\text { prison } \\
\text { sentences }\end{array}$ \\
\hline 1 & 29 & Community & 24 months & 4 & 1 \\
\hline 2 & 35 & Community & 12 months & 0 & 0 \\
\hline 3 & 39 & Licence & 10 months & 4 & 2 \\
\hline 4 & 39 & Community & 12 months & 1 & 0 \\
\hline 5 & 27 & Community & 12 months & 0 & 0 \\
\hline 6 & 21 & Community & 12 months & 2 & 0 \\
\hline 7 & 24 & Community & 6 months & 1 & 0 \\
\hline 8 & 43 & Licence & 12 months & 0 & 0 \\
\hline 9 & 18 & Community & 6 months & 0 & 0 \\
\hline 10 & 28 & Licence & 12 months & 1 & 2 \\
\hline 11 & 39 & Community & 12 months & 0 & 1 \\
\hline 12 & 30 & Community & 18 months & 2 & 1 \\
\hline 13 & 44 & Community & 24 months & 3 & 1 \\
\hline 14 & 22 & Community & 18 months & 0 & 0 \\
\hline 15 & 24 & Community & 6 months & 0 & 0 \\
\hline 16 & 29 & Licence & 18 months & 0 & 0 \\
\hline 17 & 39 & Community & 18 months & 1 & 0 \\
\hline 18 & 24 & Community & 12 months & 1 & 0 \\
\hline 19 & 36 & Community & 12 months & 0 & 0 \\
\hline 20 & 39 & Licence & 12 months & 10 & 5 \\
\hline 21 & 31 & Community & 12 months & 0 & 0 \\
\hline
\end{tabular}

This data shows that the women offenders were at different levels across the sentencing tariff and thus a diversity of experiences was captured within a relatively 
small sample of respondents. All respondents identified as White British; this reflected the ethnic make-up of the SW research site but not the more ethnically diverse probation caseload of the SE research site. However, ethnicity was not used as a factor in purposive sampling in this study.

There was a relatively wide range of ages, with the youngest being 18 and the oldest 45 with a mean age of 31.4 years. 14 out of the 21 female participants said that they had children aged 18 or under. It was difficult to deconstruct some situations in a precise way but two respondents revealed that their children were in foster care; another said that her friend had a residency order for her son; another said that her children had been adopted.

The qualitative comments from the women regarding their personal relationships often indicated turbulent situations, as illustrated by Respondent 1 who said:

"It was three years ago I left him. But obviously previous to that I was trying to get the kids back when I was with him, but social services said in the end, cause of the way he was I had to leave him... If I stayed with him I wouldn't have seen my children again... cause of domestic violence, yeah". 
To deepen understanding about their personal situations details were gathered about the type of accommodation the women respondents were living in. These responses conveyed an impression of relative stability of housing for most. However, there was a more mixed picture from a few of the respondents. For instance, Respondent 18 , who was living in a council flat, said "I've had issues and people know where I live and it's just... I don't feel safe".

Additional socio-demographic descriptors were collected regarding levels of educational achievement and current employment situations. These findings indicated that many of the women respondents were dis-engaged from work or training ${ }^{3}$. Most provided only brief responses in this part of the interview, although Respondent 17 was more expansive in her reply, saying:

“I'd like to further my education. I'd obviously love to. But it's finding the right places that would take me. Um, you know, I'm on benefits at the minute. Sometimes for some courses you've got to pay for them, you know. I can't afford to pay for them". 
These responses convey the interconnected personal and social problems experienced by many of the female respondents. These are mirrored in the research literature in relation to women offenders (see, for example, Bloom, Owen and Covington 2004; Byrne and Trew 2008), and in the difficulties for them in developing resilience and finding pathways out of crime (Rumgay 2004).

\section{Overview of health problems}

Table 2 below presents a summary of the health problems reported by each of the respondents. It is striking that many of the women were experiencing co-morbidities involving physical and mental health conditions, alongside substance misuse issues; the most commonly reported condition was asthma which was experienced by 14 of the respondents.

Table 2: Self-reported health problems and health care contacts over the past six months

\begin{tabular}{|l|l|l|}
\hline Respondent & Self-reported health problems & $\begin{array}{l}\text { Health care contacts (minutes } \\
\text { per contact) }\end{array}$ \\
\hline 1 & Asthma, Cancer, Migraine & $\begin{array}{l}1 \times \mathrm{GP}(10) \&(20), 2 \times \text { hospital } \\
(30)\end{array}$ \\
\hline 2 & & $\begin{array}{l}1 \times \text { Drug \& Alcohol worker (60), } \\
1 \times \text { GP (10) }\end{array}$ \\
\hline 3 & Asthma, Epilepsy/fits, Psoriasis, Nervous illness & $1 \times$ GP (5) \\
\hline
\end{tabular}




\begin{tabular}{|c|c|c|}
\hline 4 & $\begin{array}{l}\text { Asthma, Chronic bronchitis, Cramps in hands, Severe } \\
\text { depression, Alcohol dependency }\end{array}$ & $\begin{array}{l}2 \times \text { GP (10), } 2 \times \text { Drug \& Alcohol } \\
\text { worker (60) }\end{array}$ \\
\hline 5 & $\begin{array}{l}\text { Back and neck problems, Headaches, Reproductive } \\
\text { Health }\end{array}$ & $\begin{array}{l}3 \times \text { GP (5), } 1 \text { x GP (10), } 1 \times \\
\text { Practice Nurse (20), } 1 \text { x Family } \\
\text { Planning (40) }\end{array}$ \\
\hline 6 & $\begin{array}{l}\text { Depression, Asthma, Panic attacks, Chest infection, } \\
\text { Alcohol misuse }\end{array}$ & $\begin{array}{l}2 \times \text { Prison GP (20), } 1 \text { x GP (5), } 8 \times \\
\text { Alcohol support worker (60) }\end{array}$ \\
\hline 7 & Asthma, Back pain, Depression, Panic attacks & $3 \times \mathrm{GP}(60)$ \\
\hline 8 & $\begin{array}{l}\text { Asthma, Muscular skeletal, Emphysema, COPD, } \\
\text { Headaches, Eczema, Dyslexia, Depression, Anxiety, } \\
\text { Panic attacks, Alcohol misuse, Lazy eye, Period } \\
\text { problems, Hay fever. }\end{array}$ & $\begin{array}{l}1 \times \text { Prison GP (25), } 1 \text { x GP (10), } 8 \\
\text { x Drug and Alcohol worker (90) }\end{array}$ \\
\hline 9 & $\begin{array}{l}\text { Asthma, Back pain, Knee pain, Psoriasis, Dyslexia, } \\
\text { Psychosis, Schizophrenia, Depression, Self-harm }\end{array}$ & $\begin{array}{l}2 \times \text { Asthma nurse (20), } 1 \times \text { GP } \\
(15) \&(20) \&(30) \&(40), 12 \times \\
\text { Community Psychiatric Nurse } \\
(90)\end{array}$ \\
\hline 10 & $\begin{array}{l}\text { Back pain, Drug misuse, Chest problems, Depression, } \\
\text { Anxiety }\end{array}$ & $\begin{array}{l}1 \times \text { Prison nurse (2), } 3 \times \text { Prison } \\
\text { GP (5), } 1 \times \text { Drug and Alcohol } \\
\text { worker ( }(30)\end{array}$ \\
\hline 11 & $\begin{array}{l}\text { Joint pain, Hepatitis, COPD, Heroin, Benzodiazepines, } \\
\text { Amphetamines, DVT, Poor walking }\end{array}$ & 6 x Drug \& Alcohol worker (15) \\
\hline 12 & $\begin{array}{l}\text { Back pain, Tendonitis, Psoriasis, Cannabis, Abnormal } \\
\text { cells under investigation, Cyst on ovaries }\end{array}$ & $\begin{array}{l}1 \times \text { GP }(10), 1 \times \text { Hospital } \\
\text { consultant (30), } 1 \times \text { Community } \\
\text { Nurse (5) }\end{array}$ \\
\hline 13 & Muscular skeletal, Headaches, Dyslexia, Depression & $\begin{array}{l}2 \times \text { GP (30), } 1 \text { x Dyslexia support } \\
(60)\end{array}$ \\
\hline 14 & $\begin{array}{l}\text { Back pain, Heart problems, Headaches, Herpes, } \\
\text { Heroin, Cannabis }\end{array}$ & \\
\hline 15 & Asthma, Dyslexia, Depression & $1 \times$ GP (10) \\
\hline 16 & Asthma, Anaemia & $\begin{array}{l}1 \times \text { Prison nurse \& Prison GP } \\
(10), 1 \text { x Prison nurse }(10)\end{array}$ \\
\hline 17 & $\begin{array}{l}\text { Asthma, Back pain, Chronic bronchitis, Eczema, STD, } \\
\text { Common mental health problems, Heroin, Crack, Leg } \\
\text { problem, Cancer }\end{array}$ & $\begin{array}{l}7 \times \text { Drug worker (10), } 15 \times \text { Drug } \\
\text { worker (240), } 21 \text { x Prison GP } \\
\text { (10), }\end{array}$ \\
\hline 18 & Asthma, Depression, Paranoia, Alcohol misuse & $3 \times \mathrm{GP}(10)$ \\
\hline 19 & $\begin{array}{l}\text { Slipped disc in back, Migraines, Learning disability, Bi- } \\
\text { polar disorder, Depression, Anxiety, Alcohol misuse }\end{array}$ & $\begin{array}{l}1 \times \text { x GP (5) \& (10) \& (20). } 6 \text { x } \\
\text { Alcohol worker (90) }\end{array}$ \\
\hline 20 & $\begin{array}{l}\text { Asthma, Sciatica, Epilepsy, Fits, Depression, Anxiety, } \\
\text { Panic attacks, Heroin, Benzodiazepines, Methanol }\end{array}$ & $\begin{array}{l}1 \times \text { x GP (5), } 1 \text { x Drug worker } \\
\text { (300), } 12 \text { Drug worker (20) }\end{array}$ \\
\hline 21 & $\begin{array}{l}\text { Asthma, Heart palpitations, Personality disorder, } \\
\text { Depression, Anxiety, Heroin }\end{array}$ & $\begin{array}{l}2 \times \text { Mental Health worker (30), } 2 \\
\text { x GP (15) \& (30), } 4 \text { x Drug } \\
\text { worker (5), } 1 \text { x Drug worker (60) }\end{array}$ \\
\hline
\end{tabular}


These details have considerable impact given the extensive range and multiplicity of health problems that this overview reveals, particularly given the relatively young age range of the respondents. The daily burden of the variety of health issues for each woman is indeed shocking. It is also important to recognise the generalisability of these findings: for instance, Covington (2007) noted similar medical histories amongst female offenders in the USA, expressing her concern that "women and girls at risk for criminal justice involvement are an underserved population that often is disconnected from health care, other treatment services, and information about prevention" (Covington 2007: 180). She went on to recommend that:

Addressing the health and mental health needs of women and girls involves the development of comprehensive, coordinated services. A continuity-of-care model integrates services that address their histories of poverty and trauma, recognize their mental and physical health issues, and incorporate the emotional and psychological components that women and girls need to heal and recover.

\section{Reviewing Total Continuity of Care for Women Offenders}


This article now goes on to explore the qualitative responses of the women participants in our research study in order to review issues connected with addressing the constellation of such problems and further explores the application of an existing model of continuity of care. 'Continuity of care' has been outlined as "a complex, multi-element relational concept" (Freeman et al 2002: 8) and is considered "an essential feature of good quality care" (Jones et al 2009: 632). The particular elements reviewed below relate to four aspects of 'continuity of care': longitudinal continuity of access; individual relationships; flexibility; and communication (see Byng et al. 2012).

Progressive policy and practice for women offenders in England and Wales from early in the millennium in England and Wales, and particularly following the Corston Report (2007), encouraged the adoption of holistic, multi-disciplinary responses, with women's centres providing an inclusive 'one-stop shop' approach (Roberts 2002). However, the Stocktake of Women's Services for Offenders in the Community (NOMS 2013 ) indicated that there were only 53 women's centres or hubs across England and Wales, many of which were on short-term contracts. The implementation of TR further destabilised the situation, with Dame Glenys Stacey, Chief Inspector of Probation finding "funding reductions and uncertainties, a lack of strategic or 
operational focus on outcomes for women, and no better monitoring and evaluation that when we reported in 2011" (HM Inspectorate of Probation 2016: 5)

The responses by the participants in our study provide insights into the perceptions of women offenders and, importantly, their viewpoints of their interactions with and between criminal justice agencies and healthcare providers in such situations.

\section{Longitudinal continuity of access}

Continuity of access over time between the female offenders and probation staff ${ }^{4}$ derives from their position as 'involuntary clients' (Trotter 2015). However, while this puts a statutory framework in place for such involvement, the chaotic lifestyles of some women offenders make maintaining contact over a period of time challenging to achieve. The nature of such supervisory contact also foregrounds punitive sanctions for non-compliance, which puts in place a continual tension between care and control in terms of probation interventions with women offenders.

Moreover, for many of the women their probation contact was only one part of a wider range of interventions connected with the range of issues and problems they 
were experiencing. Such a situation became apparent when Respondent 7 spoke about the counselling she was receiving via a referral made by her GP:

Respondent 7: It was supposed to be every week, but sometimes I couldn't make it so it ended up being over about three months, twothree months.

When asked about her contact with the counsellor Respondent 7 replied "at the time she helped me, she's brilliant". However, the ensuing conversation then revealed a more complex picture, particularly concerning the interactions between the health and criminal justice services:

Researcher: $\quad$ So after that, so that's sort of just before the summer, did you see the doctor at all or anybody else about the depression? Did it all seem to be going quite well?

Respondent 7: $\quad$ Uh-huh.

Researcher: What about when you came into court or when you came onto probation? You said to me that they were going to get you into 
a counsellor again, they sort of advised you to go for a counsellor again, the probation.

Respondent 7: $\quad$ Yeah. I've got to do victim awareness, so I've got to have a counsellor and anger management.

Researcher: $\quad$ Okay. And have you seen anybody with this? You're seeing about victim awareness and the counsellor today?

Respondent 7: $\quad$ I don't know when I'm doing that, but I'm going to see... I was raped about five years ago so I'm seeing someone who specialises in that on Monday.

Researcher: Okay.

Respondent 7: $\quad$ And then I've got to have anger management, but I need to do that before I have anger management.

This extract illustrates how the woman's emotions - hurt, anger, low mood - were dealt with by different silo based services. The complexity of Respondent 7's needs and problems also resonates with the findings from the Corston Report (2007) and the concerns expressed there about the vulnerabilities of women caught up in the criminal justice system. While Respondent 7 conveyed a sense that there was intended to be 
some sequencing in terms of the interventions she was due to receive, it appears that these had been framed in criminogenic and organisational terms by the criminal justice and health agencies, rather than her own whole-woman needs. This has far-reaching implications for women such as Respondent 7, as Hannah-Moffat (2005: 43) has indicated:

Correctional interventions are prioritized according to what is pragmatic, rather than what may be meaningful to the offender but 'unachievable', because interventions hinge on broader social and structural inequalities, or gaps in services.

In this respect, women offenders such as Respondent 7, with such an extensive and troubling range of problems, find themselves at a jarring nexus of criminal justice and health interventions, each underpinned by differing priorities, objectives and targets. In order for effective holistic approaches to be applied, which would support longitudinal continuity for individuals, co-ordinated work is needed, cutting across organisational and agency boundaries, much as envisaged by Corston (2007). In addition, as noted by Hannah-Moffat (2013: 142), correctional assessment strategies and policies need to move beyond "narrow understandings of women's 'risks and 
needs'". Regretfully, these visions have made little progress over the past ten years in England and Wales (Women in Prison 2017) and seem likely to retreat still further given the cut-backs imposed by austerity measures and the challenges and fragmentation brought about by the Transforming Rehabilitation changes (see HM Inspectorate of Probation 2017).

\section{Individual relationships}

In their study which looked at continuity of care within health settings, Freeman and Hughes (2010) viewed good practice as being encapsulated in relationships. This was spoken about by Respondent 19:

Respondent 19: $\quad$ My previous doctor... she knew of my drinking background, she knew of my family background, she knew of my mental health history.

Researcher: $\quad$ Right...

Respondent 19: $\quad$ But what happened when I saw my new doctor was after the event when I was arrested for drink-driving. I saw her the day 
after to tell her what had happened, and she just looked at me like I was a complete idiot, and not at all sympathetic.

In the follow-up interview several months later Respondent 19's relationship with the new GP had deteriorated still further as indicated by her comments that "my doctor, she don't know nothing about me now... She just thinks I'm a criminal". Concerns about being stigmatised or labelled came through strongly here; as Hedderman, Gunby and Shelton (2011: 10) observed "the relationship of trust is fragile and important", while Malloch and Mclvor (2011: 331) have commented that "women who commit crimes are stigmatized on the basis that they have broken social laws; but are additionally stigmatized for breaking gendered codes of 'appropriate' behaviour for women".

In summary, the women respondents' contacts with healthcare professionals were undoubtedly complicated by the complexities of their situations, where their medical issues were often inter-connected with their psychological and social difficulties, but were not addressed in a holistic way. Indeed, the presenting problems sometimes seemed to be concealing more deep-seated and unresolved concerns but were covered over by more ambivalent, diffident or defensive modes of presentation 
(Donelle and Hall 2016). The findings regarding the women respondents from the COCOA report (2012) supported these observations.

\section{Flexibility}

Within health care settings the importance of practitioners being able to work in flexible ways to meet the needs of individuals, even when working within rigid systems, has been emphasised. However, for some of the women participants in this study the disruptions they had experienced from being in custody, and / or the on-going problems of coping with day-to-day living, particularly when impacted by aspects relating to their health problems, sometimes seemed insurmountable. For instance, Respondent 3 stated:

"I was away quite a long time, so I've sort of... it's difficult getting back into normality. You know, and it's like little things that make sense to everyone else, like some things don't make sense to me".

Moreover, the sense of emotional dislocation for some of the women should not be under-estimated. For example, Respondent 15 was living with her husband but he had significant mental health issues, leading her to comment that: 
"I'm not part of the community. I'm not even part of my family really at the moment because of him. So... my Mum yeah, but generally no".

When asked how she coped with her asthma attacks she commented:

“I don't bother. I'm scared of hospital so... and that's the only other option they have for me when I can't... when I struggle to breathe, so I just don't go near them. I just, we move back to my Mum's... It's one of them things".

A vicious cycle seemed to be emerging for many of the women offenders: their health problems had a detrimental impact on attempts they were trying to make to stabilise their lives, but from their disadvantaged positions they were struggling (and often failing) to engage in a meaningful way, mainly because of the lack of flexibility within services to work around their range of needs. In this respect Allen's call to "shrink the system of punishment and to develop measures instead which systematically seek to build the capacity of communities to prevent, absorb and cope with crime and insecurity" (Allen 2013: 14), seems particularly apposite. Indeed the complex care 
needs of the women were in direct tension with the often inflexible and controlling strictures of the criminal justice and health agencies they came into contact with.

\section{Communication}

This section considers issues of communication and, in particular the pro-active inclusion of the offenders themselves in this process. The COCOA study acknowledged the information-transfer problems that can occur between healthcare and criminal justice agencies and which can lead to duplication of assessment. This can be costly, time-consuming and may lead to delays in timely interventions and treatment (Byng et al. 2012: 194).

The majority of the women, when asked questions about health and criminal justice agencies sharing information about them, supported the principle of informationsharing, with some, such as Respondent 9 asserting that "they already know about them type of things anyway". However, Respondent 14 was much more wary about communication across agencies, saying "I don't wanna be labelled by anyone". These responses regarding issues of communication to achieve continuity of care show the delicate balance in trying to address and provide services in relation to the interconnected problems experienced by female offenders (see Rodermond et al 2016). 


\section{Policy and Practice - Recent Development Impacting on Women Offenders}

Within the criminal justice sphere in England and Wales policy and practice developments over recent years have built on recommendations from the Corston Report (2007), with research in this area propounding key tenets which have underpinned provision for women offenders (see Gelsthorpe 2011). A number of holistic, women-centred and multi-agency settings across England and Wales were developed in line with this approach (Plechowicz 2015). However, more recently these initiatives have been operating within the wider background of a neo-liberal approach to offender management (Burke and Collett 2015). In a climate in England and Wales of resource constraints and cutbacks this has increasingly posed difficulties in maintaining such services for women offenders.

In this respect scepticism about the TR agenda in relation to women offenders (Gelsthorpe and Hedderman 2012; Radcliffe and Hunter 2015) sadly seems to have been proved right, as evidenced by emerging reports from HM Inspectorates of Prisons and Probation and other research (see, for example, HM Inspectorate of Probation and HM Inspectorate of Prisons 2016; HM Inspectorate of Prisons 2017; Gray, Simmonds and Annison 2016). The deteriorating situation with regard to female offenders is of 
extreme concern: inter-agency collaboration is rapidly disappearing across the statutory and voluntary sectors, particularly given the fragmentation and lack of coordination and co-operation across agencies (Goodhill 2016).

In turn in the health sphere, while the Bradley Report (Department of Health 2009) and Improving Health and Support Justice (Department of Health 2007) recommended some key technical drivers to improve continuity, there was less emphasis on the development across the range of agencies in relation to the professional skills needed to facilitate collaboration and engagement in shared management and care (Byng et al. 2012: 190). Indeed, in the current climate of financial restraint and contraction it is difficult to see how a holistic approach across all of the personal, health and social problems experienced by many women offenders can be addressed, particularly given the separate commissioning processes and funding streams of different services (see, for instance, Bartlett et al 2014).

\section{Concluding Thoughts}

The issues discussed above concerning continuity of care emphasise the significance of constructive engagement involving multi-agency collaboration when working with women offenders. The different facets of continuity of access, relationships with 
individuals, flexibility and issues related to communication, were acknowledged to be complex, but of key importance in terms of "personalising transitions and situating them in the context of the daily life of service users" (Jones et al 2009: 638). Of particular note across these facets, was the ability of services to work in a holistic way, taking into account the range of the women's needs and the need of health and criminal justice services to integrate their interventions. As was stated at the end of the COCOA report:

Perhaps the most important message is that health cannot be seen as an add-on to the criminal justice process. For individuals in distress, or in denial, their social problems, their mental health problems and their CJS involvement are not only intertwined but can be seen as one and the same problem.

(Byng et al. 2012: 198)

As outlined above, individual examples of good practice in work with women offenders have emerged over the past decade following the principles from the Corston Report (2007), but they have failed to become embedded within the criminal justice system (Annison, Brayford and Deering 2015b). This is of particular concern: the theoretical health-based framework regarding 'continuity of care' and the detail and analysis of 
the empirical data outlined in this article strongly supports Corston's call for holistic, individualised and integrated responses, but takes this further to advocate the need to cut across organisational boundaries and to provide joined-up approaches between staff in criminal justice and health agencies for women offenders. This will demand political will at national level to address such issues.

Furthermore, the findings and analytical critique outlined here support the case that "the challenges women face must be met with expanded opportunity and a more thoughtful criminal justice policy" (Richie 2001: 386), in order to help women offenders address their inter-connected problems, including health, and to support their attempts to desist from crime. The findings from the COCOA study showed that, although often not achieved in the experiences of the women respondents, such interventions are most likely to function effectively when they are working with the whole range of a woman's needs and strengths, not separately on offending or health problems; when an individual's mind and body in its social context are being considered as one; and within a context where overarching policies enable criminal justice and health services are able to work collaboratively with women offenders.

\section{Acknowledgements}


Deborah Shenton, Claire Warrington and lan Porter for data collection and the wider COCOA research study team. The local Probation Services in the two areas in which the study was conducted. The authors are grateful to Professor Mike Maguire and to the two anonymous reviewers for their constructive comments on earlier drafts of the article.

\section{Declaration of Conflicting Interests}

The authors declare no potential conflicts of interest with respect to the research, authorship and / or publication of this article.

\section{Funding}

This research was supported by the National Institute for Health Research (NIHR) Collaboration for Leadership in Applied Health Research and Care South West Peninsula at the Royal Devon and Exeter NHS Foundation Trust. The views and opinions expressed therein are those of the authors and do not necessarily reflect those of the Service Delivery and Organisation Programme (SDO), National Institute for Health Research (NIHR), National Health Service (NHS), or the Department of Health.

Funding body: National Institute for Health Research Service Delivery and Organisation Programme (NIHR SDO) Project reference 08/1713/210.

\section{Notes}

${ }^{1}$ The other two broad categories of vulnerabilities are: "Domestic circumstances and problems such as domestic violence, childcare issues, being a single parent"; and, "socioeconomic factors such as poverty, isolation and employment" (Annison and Brayford 2015: 3).

${ }^{2}$ All 21 female respondents participated in a first interview, with 10 undertaking a second (follow-up) interview when contacted three to six months later.

${ }^{3}$ Information from the publication Statistics on Women and the Criminal Justice System 2013 (Ministry of Justice 2014: 60-61) stated "Female offenders were more likely to be on out-of-work benefits both before and after their caution/conviction or 
prison sentence, than male offenders. $53 \%$ of female offenders were on an out-ofwork benefit one month after conviction/caution or release from prison in the 2010/11 tax year, compared to $42 \%$ of male offenders.

${ }^{4}$ The study was conducted ahead of the implementation of the TR changes and so all of the respondents then came under the auspices of local probation trusts.

\section{References}

Allen R (2013) Paying for justice: Prison and probation in an age of austerity. British Journal of Community Justice 11(1): 5-18.

Annison J and Brayford J (2015) Corston and beyond. In: Annison J, Brayford J and Deering J (eds) Women and Criminal Justice: From the Corston Report to Transforming Rehabilitation. Bristol: Policy Press.

Annison J, Brayford J and Deering J (2015a) Conclusions. In: Annison J, Brayford J and Deering J (eds) Women and Criminal Justice: From the Corston Report to Transforming Rehabilitation. Bristol: Policy Press.

Annison J, Brayford J and Deering J (eds) (2015b) Women and Criminal Justice: From the Corston Report to Transforming Rehabilitation. Bristol: Policy Press.

Annison J, Burke L and Senior P (2014) Transforming Rehabilitation: Another example of English 'exceptionalism' or a blueprint for the rest of Europe? European Journal of Probation, 6(1): 6-23.

Asher K and Annison J (2015) Probation practice with women offenders in Wales. In: Annison J, Brayford J and Deering J (eds) Women and Criminal Justice: From the Corston Report to Transforming Rehabilitation. Bristol: Policy Press.

Bartlett A, Walker T, Harty MA and Abel KM (2014) Health and social care services for women offenders: Current provision and a future model of care. The Journal of Forensic Psychiatry \& Psychology 25(6): 625-635. 
Bloom B, Owen B and Covington S (2004) Women offenders and the gendered effects of public policy. Review of Policy Research 21(1): 31-48.

Burke L and Collett S (2015) Delivering Rehabilitation: The Politics, Governance and Control of Probation. Abingdon: Routledge.

Byng, R, Quinn C, Sheaff R, Samele C, Duggan S, Harrison D, Owens C, Smithson P, Wright C, Annison J, Brown C, Taylor R, Henley W, Qureshi A, Shenton D, Porter I, Warrington C and Campbell J (2012) COCOA, Care for Offenders, continuity of access. NIHR Service Delivery and Organisation Programme 2012.

Byrne CF and Trew KJ (2008) Pathways through crime: The development of crime and desistance in the accounts of men and women offenders. The Howard Journal of Crime and Justice 47(3): 238-258.

Chesney-Lind M and Pasko L (2013) The Female Offender: Girls, Women, and Crime (3 ${ }^{\text {rd }}$ Edition). London: Sage.

Clinks (2015) Health and care services for women offenders: A snapshot of health and care provision for women in contact with the criminal justice system. Available at: http://www.clinks.org/sites/default/files/basic/files-

downloads/health and care services for women offenders finalv2.pdf (accessed 20 June 2017.

Clinks (2016) Transforming Rehabilitation. Available at http://www.clinks.org/criminaljustice/transforming-rehabilitation (accessed 20 June 2017)

Corston J (2007) The Corston Report: A report by Baroness Jean Corston of a review of women with particular vulnerabilities in the criminal justice system. London: Home Office.

Covington SS (2007) Women and the criminal justice system. Editorial in Women's Health Issues 17(4): 180-182.

Department of Health (2007) Improving health, supporting justice: A consultation document. A strategy for improving health and social care services for people subject to the criminal justice system. London: Department of Health. 
Department of Health (2009) The Bradley Report: Lord Bradley's review of people with mental health problems or learning disabilities in the criminal justice system. London: Department of Health.

Donahue KE, Ashkin E and Pathman DE (2005) Length of patient-physician relationship and patients' satisfaction and preventive service use in the rural south: A crosssectional telephone study. BMC Family Practice 6: 40.

Donelle L and Hall J (2016) An exploration of women offenders' health literacy. Social Work in Public Health 29(3): 240-251.

Freeman G and Hughes J (2010) Continuity of care and the patient experience. London: The Kings Fund.

Freeman G, Shepperd S, Robinson I, Ehrich E and Richards S (2001) Continuity of care Report of a scoping exercise. London: NCCSDO.

Freeman G, Weaver T, Low J, de Jonge E and Crawford M (2002) Promoting continuity of care for people with severe mental illness whose needs span primary, secondary and social care: A multi-method investigation of relevant mechanisms and contexts.

London: HMSO.

Gelsthorpe $L$ (2011) Working with women offenders in the community: A view from England and Wales. In Sheehan R, Mclvor G and Trotter C (eds), Working with Women Offenders in the Community. Cullompton: Willan, pp.127-150.

Gelsthorpe L and Hedderman C (2012) Providing for women offenders: The risks of adopting a payment by results approach. Probation Journal 59(4): 374-390.

Gelsthorpe L, Sharpe G and Roberts J (2007) Provision for women offenders in the community. London: Fawcett Society.

Gomm R (2013) What will 'count' and be transformed for women in the criminal justice system? British Journal of Community Justice 11(2/3): 153-158. 
Goodhill R (2016) Reflecting on working with vulnerable women: Connecting, cans of worms, closures and coping. British Journal of Social Work 46(5): 1336-1353.

Gray, P, Simmonds L and Annison J (2016) The resettlement of women offenders: learning the lessons: a research project focusing on the experience of the female offender. Part of the Cornwall VSF Promoting Change Project. Available at https://pearl.plymouth.ac.uk/handle/10026.1/9239

Hammersley M (2002) Systematic or unsystematic, is that the question? Text of a talk given to the Public Health Evidence Steering Group of the Health Development Agency. Available at https://www.researchgate.net/publication/42798662 Systematic or unsystematic is that the question Reflections on the science art and politics of reviewing rese arch evidence (accessed 20 June 2017)

Hannah-Moffat K (2005) Criminogenic needs and the transformative risk subject: Hybridizations of risk / need in penality. Punishment and Society 7(1):7-29.

Hannah-Moffat K (2013) Punishment and risk. In: Simon, J. and Sparks, R. (eds) The SAGE Handbook of Punishment and Society. London: Sage, pp. 129-151.

Hedderman C, Gunby C and Shelton N (2011) What Women Want: The importance of qualitative approaches in evaluating work with women offenders. Criminology \& Criminal Justice 11(1): 3-19.

Hedderman C, Palmer EJ and Hollin CR (2008) Implementing services for women offenders and those 'at risk' of offending: Action research with Together Women. Ministry of Justice Research Series 12/08. London: Ministry of Justice.

HM Inspectorate of Prisons (2017) Report on an unannounced inspection of HMP Eastwood Park. London: HM Inspectorate of Prisons.

HM Inspectorate of Probation (2016) A thematic inspection of the provision and quality of services in the community for women who offend. Manchester: HM Inspectorate of Probation. 
HM Inspectorate of Probation (2017) Annual Report. Manchester: HM Inspectorate of Probation.

HM Inspectorate of Probation and HM Inspectorate of Prisons (2016) An inspection of Through the Gate resettlement services for short-term prisoners. Manchester: HM Inspectorate of Probation.

House of Commons Justice Committee (2013) Women Offenders - After the Corston Report, $2^{\text {nd }}$ Report 2013-2014 Vol. 1. London: The Stationery Office.

Jones IR, Ahmed N, Catty J, McLaren S, Rose D, Wykes T and Burns T (2009) IIIness careers and continuity of care in mental health services: A qualitative study of service users and carers. Social Science \& Medicine 69: 632-639.

Kearley KE, Freeman GK and Heath A (2001) An exploration of the value of the personal doctor-patient relationship in general practice. British Journal of General Practice 41(470): 712-8.

Lester H, Tritter JQ and Sorohan H (2005) Patients' and health professionals' views on primary care for people with serious mental illness: Focus group study. British Medical Journal 330(7500): 1122-8.

Mclvor G, Trotter C and Sheehan R (2009) Women, resettlement and desistance. Probation Journal 56(4): 347-361.

Malloch M and Mclvor G (2011) Women and community sentences. Criminology and Criminal Justice 11(4): 325-344.

Ministry of Justice (2013) Transforming justice: A strategy for reform. London: Stationery Office.

Ministry of Justice (2014) Statistics on women and the criminal justice system 2013: A Ministry of Justice publication under Section 95 of the Criminal Justice Act 1991. London: Ministry of Justice.

National Offender Management Service (NOMS) (2013) Stocktake of women's services for offenders in the community. London: NOMS. 
Nutting P, Goodwin M, Flocke S, Zyzaski S and Stange K (2003) Continuity of primary care: To whom does it matter and when? Annals of Family Medicine 1(3): 149-55.

Pawson R and Tilley N (1997) Realistic evaluation. London: Sage.

Plechowicz L (2015) Women's centres. In: Annison J, Brayford J and Deering J (eds) (2015) Women and Criminal Justice: From the Corston Report to Transforming Rehabilitation. Bristol: Policy Press, pp.119-136.

Prison Reform Trust (2013) Prison Reform Trust briefing on the Offender Rehabilitation Bill, House of Commons Second Reading 11 November 2013. Available at http://www.prisonreformtrust.org.uk/Portals/0/Documents/Prison\%20Reform\%20Tru st\%20Briefing\%20Offender\%20Rehabilitation\%20Bill\%20HoC\%202nd\%20Reading\%201 1Nov13.pdf (accessed 20 June 2017).

Radcliffe P and Hunter G (2015) 'It was a safe place for me to be': Accounts of attending women's community services and moving beyond the offender identity. British Journal of Criminology 56(5): 976-994.

Richie BE (2001) Challenges incarcerated women face as they return to their communities: Findings from life history interviews. Crime \& Delinquency 47(3): 368389.

Roberts J (2002) Women-centred: The West Mercia community-based programme for women offenders. In: Carlen P (ed) Women and Punishment: The Struggle for Justice. Cullompton: Willan, pp. 110-124.

Rodermond E, Kruttschnitt C, Slotboom A-M and Bijleveld CCJH (2016) Female desistance: A review of the literature. European Journal of Criminology 13(1): 3-28.

Ross RR and Fabiano EA (1987) Female Offenders: Correctional Afterthoughts. Jefferson, NC: McFarland.

Rumgay J (2004) Scripts for safer survival: Pathways out of female crime. The Howard Journal of Criminal Justice 43(4): 405-19. 
Schers H, Webster S, van der Hoogen H, Avery A, Grol R and van der Bosch W (2002) Continuity of care in general practice: A survey of patients' views. British Journal of General Practice 52: 459-62.

Seal L and Phoenix J (2013) Raw deal: The curious expansion of penal control over women and girls. In: Dockley A and Loader I (eds) The Penal Landscape: The Howard League Guide to Criminal Justice in England and Wales. Abingdon: Routledge, pp. 167188.

Sheehan R, Mclvor G and Trotter C (2007) (eds) What Works with Women Offenders. Cullompton: Willan.

Sheehan R, Mclvor G and Trotter C (2011) (eds) Working with Women Offenders in the Community. Cullompton: Willan.

Strickland P (2016) Contracting out Probation Services 2013-2016. Briefing Paper Number 06894, House of Commons Library. Available at http://researchbriefings.parliament.uk/ResearchBriefing/Summary/SN06894 (accessed 20 June 2017)

Tarrant C, Windrige K, Boulton M, Baker R and Freeman GK (2003) Qualitative study of the meaning of personal care in general practice. General Medical Journal 326: 131015.

Trotter C (2015) Working with Involuntary Clients: A Guide to Practice (3 ${ }^{\text {rd }}$ Edition). Abingdon: Routledge.

Women in Prison (2017) The Corston Report 10 years on: How far have we come on the road to reform for women affected by the criminal justice system? Available at http://www.womeninprison.org.uk/perch/resources/corston-report-10-years-on.pdf (accessed 20 June 2017).

\section{Author biographies}

Jill Annison is Associate Professor in Criminal Justice Studies at the University of Plymouth, UK. Her early professional career included roles as a probation officer and 
as a social worker in a remand and assessment centre for girls. Her academic career has focused on probation and women offenders.

ORCID ID: 0000-0002-5441-6525

Richard Byng is Professor in Primary Care Research at the University of Plymouth, Faculty of Medicine and Dentistry. He is a practising GP, works in the probation setting and has focused his research on redesign of healthcare organisation and practice for individuals with complex needs.

ORCID ID: 0000-0001-7411-9467

Cath Quinn is a Senior Research Fellow at the University of Plymouth, Faculty of Medicine and Dentistry. She is a qualitative methodologist, with a special interest in mental health, working with socially marginalised groups.

ORCID ID: 0000-0003-4644-4603 